\title{
La industria de materiales básicos de construcción ante las ingentes necesidades actuales de edificación
}

\author{
The basic construction materials industry \\ and today's vast housing shortage
}

\author{
$\underline{\text { J. Salas }}^{(*)}$ e I. Oteiza $(*)$
}

Recepción/Received: 19-II-08

Aceptación/Accepted: 4-VI-08

Publicado online/Online publishing: 1-XII-08

\section{RESUMEN}

El trabajo aborda en forma documentada, algunos aspectos del mayor de los retos que tiene planteado a nivel cosmopolita el sector de la edificación: las ingentes necesidades de habitabilidad básica que padece la humanidad, centrándose en forma monográfica en lo que ello supone para la industria de materiales básicos de edificación. Necesidades que se traducen en la mayor demanda histórica de soluciones ex-novo y en el aumento exponencial de rehabilitación y mejora de tugurios, que los autores traducen en necesidades de materiales de construcción, y de forma más concreta, de cemento, como material emblemático de la edificación.

El trabajo, mediante el análisis de casos, muestra la muy diferente repercusión que tienen los materiales sobre los presupuestos finales de lo ejecutado, según se trate del mundo desarrollado (MD) o de países en vías de desarroIlo (PVD). Por otra parte, estudia la incidencia general del sector 'informal' de la construcción, concluyendo que éste, en muchos países, es el consumidor mayoritario de materiales -specialmente cemento-y que a nivel mundial los PVD lo son tanto en producción como en consumo.

Palabras clave: necesidades de materiales, producción de cemento, sector "informal", repercusión de los materiales, Tercer Mundo.

\section{SUMMARY}

This paper documents some of the aspects of the major challenge facing world-wide building: humanity's daunting shortage of basic housing, monographically focusing on what this means for the basic building materials industry. These needs have created the greatest demand ever for ex-novo solutions and an exponential increase in slum rehabilitation and improvement, translated here into the need for construction materials and more specifically, cement, as the emblematic component of buildings.

Based on case studies, the article explores the differential impact of materials on final building costs in the developed world (DW) and developing countries (DC). It also studies the general consequences of "informal" construction, concluding that in many countries this sector consumes a major share of materials, particularly cement, and that globally speaking DCs are both the largest producers and consumers of that product.

Keywords: need for materials, cement production, "informal" sector, impact of the cost of materials, Third World.

(*) Instituto de Ciencias de la Construcción Eduardo Torroja, CSIC (Madrid, España). 


\section{PARADIGMAS SUSTANTIVOS DE LAS ACTUALES NECESIDADES DE ALOJAMIENTO}

\subsection{El imparable crecimiento de las necesidades}

Planteamiento cosmopolita del tema

En el mapa mundial del reparto del PIB planetario, la geografía de la pobreza se superpone a la de las ingentes necesidades de cobijo y vivienda, las mayores que hayan existido nunca en la historia de la humanidad. Ambas, pobreza y precariedad de viviendas, se concentran, salvo contadas excepciones, en las regiones en vías de desarrollo: Asia, África y América Latina. La situación de estas poblaciones se torna aún más dramática cuando, partiendo de la visión estática del presente, se intenta vislumbrar el mañana. De los 6.677 millones de habitantes del planeta al inicio de 2008, el 77\% (5.140 millones) habita en PVD, mientras que el $23 \%$ restante (1.537 millones) lo hace en el MD. El MD presenta una población sensiblemente estable, que sólo crece como consecuencia de las migraciones procedentes de algunos PVD. Todo apunta a la consolidación de la sociedad urbana del MD, demográfica y físicamente estable, mientras que los PVD se proyectan como un proceso de enorme crecimiento demográfico y de urbanización acelerada. Proceso de rápida urbanización mediante el que tratarán de asentarse tanto los incrementos vegetativos de los respectivos países como sus migraciones rurales al medio urbano (1).

Al convocar el Día Universal del Hábitat (2007) la Secretaria General de UN - Hábitat, Anna Tibaijuka, anunciaba: "...2007 será el año en el que por primera vez, la mitad de la humanidad vivirá en ciudades. Esto marca el comienzo de una nueva era urbana. Y las previsiones indican que para 2030 esta proporción aumentará hasta los dos tercios. Las ciudades que crecerán en forma más rápida serán las del mundo en desarrollo y aún crecerán más rápidamente los tugurios" (2).

Tal y como muestra la Figura 1, entre 1999 y 2012 el mundo está experimentando un crecimiento neto de población de 1.000 millones de seres, pasando de 6.000 a 7.000 millones de habitantes. Resulta estremecedor pensar que desde el paleolítico hasta el año 1811 no se alcanzaron los primeros 1.000 millones de habitantes en la Tierra, y que ahora, en tan sólo 13 años, la población aumentará en otros mil millones. ¿Qué significa un dato así desde la óptica de este trabajo?, pues que durante el siguiente lustro habrá que alojar anualmente una media de 77 millones de nuevos seres, lo que adoptando el ratio de 4,5 convivientes de media por alojamiento, supondría tener que construir anualmente unos 17 millones de nuevos alojamientos en todo el mundo, es decir, del orden de 680 millones de metros cuadrados (a razón de $40 \mathrm{~m}^{2}$ por

\section{SUBSTANTIVE PARADIGMS OF TODAY'S HOUSING NEEDS}

\subsection{The relentless growth of needs}

\section{Cosmopolitan approach to the subject}

On the world map of planetary GDP, the geography of poverty concurs very closely with the regions having a dramatic shortage of shelter and housing, the largest that has ever existed in the history of humanity. Both poverty and precarious housing cluster, with very few exceptions, in the developing world: Asia, Africa and Latin America. The future plight of these peoples, predicted on the grounds of the present circumstances, is even more distressing. Of the 6,677 billion human beings inhabiting the planet in early 2008, 77\% (5,14 billion) lived in developing countries and the remaining $23 \%$ (1,537 billion) in the $D W$. The latter has an essentially stable population, which only grows as a result of the migrations from some of the DCs. There is every indication that demographically and physically stable urban society will prevail in the DW, while the DCs are expected to undergo enormous population growth and accelerated urbanization. This process will be driven by the attempts of both natural population increases in the respective countries and rural migrants swarming to urban environments to settle in cities (1).

When announcing Universal Habitat Day (2007), Executive Director of UN-Habitat Anna Tibaijuka noted that in 2007, for the very first time, half of the world's population was living in cities. This, according to Ms Tibaijuka, marked the beginning of a new urban era. She added that the percentage was projected to rise to two thirds by 2030 and that cities in the developing world would grow the fastest, with slums growing even faster (2).

As Figure 1 shows, in 2012 there will be one billion (1 $\mathrm{x}$ 109) more human beings on the planet than there were in 1999, for a total of seven, up from six billion people. It is alarming to think that the human species, after inhabiting the planet since the Palaeolithic Period, did not have a total population of one billion until 1811, while just two centuries later, it will increase its numbers by that amount in only 13 years. What such a fact means from the vantage of the present study is that housing will have to be built for an additional 77 million people per year. Assuming an average of 4.5 inhabitants per dwelling, around 17 million new dwellings or on the order of 690 million more square metres (assuming $40 \mathrm{~m}^{2}$ per unit) will have to be erected. That is paramount to producing and using 600 million cubic metres or about 1.5 billion 
solución construida) o, lo que es equivalente, producir y utilizar más de 600 millones de metros cúbicos de materiales de construcción, unos 1.500 millones de toneladas anuales de materiales, componentes y subsistemas constructivos; y eso, sólo para atender la edificación de las nuevas necesidades generadas por el incremento vegetativo de población.
(109) tonnes of construction materials, components and subsystems annually, simply to meet the new housing needs generated by the natural increase in the population.

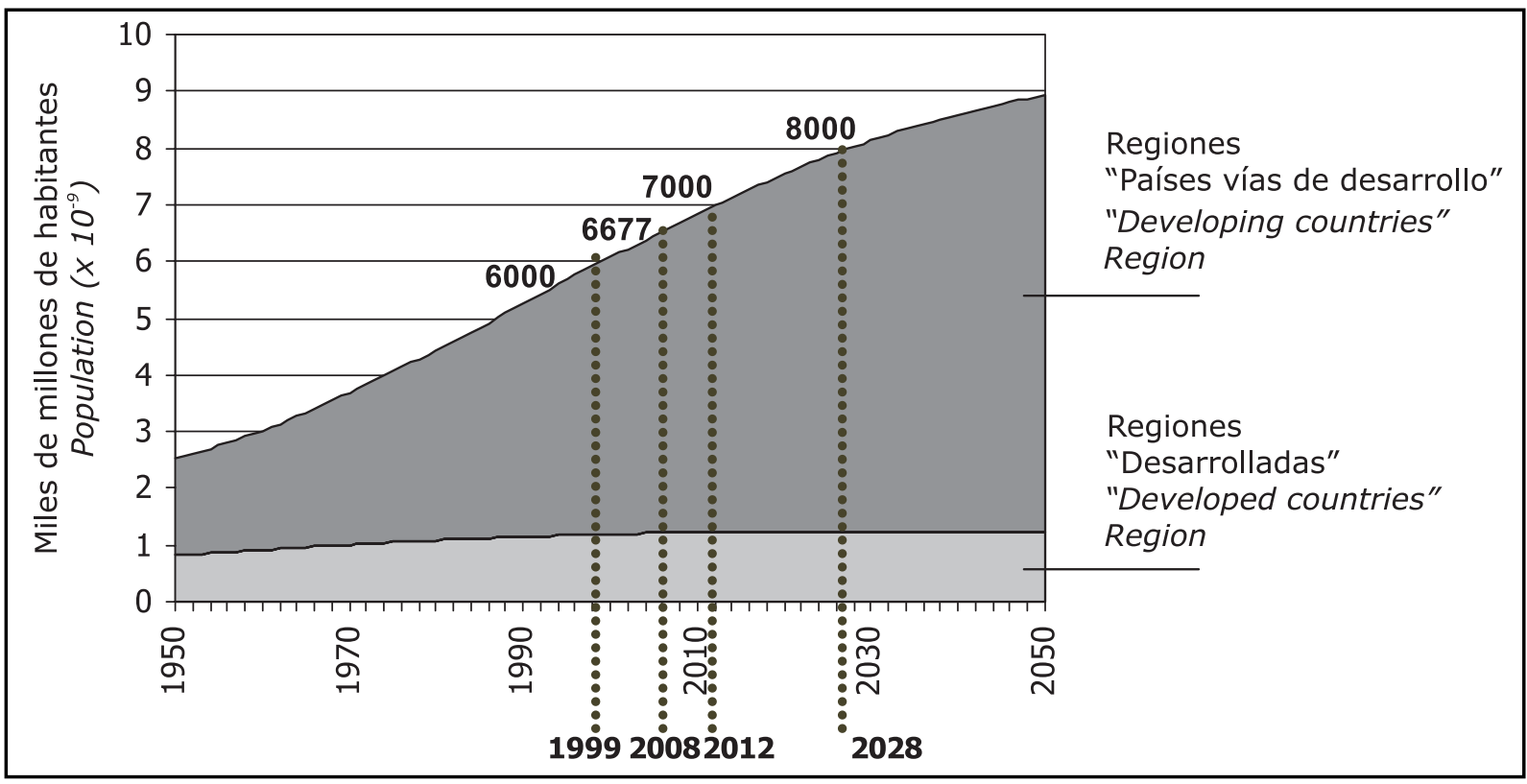

Figura 1. Crecimiento de la población mundial según regiones "en desarrollo" y "desarrolladas" (1950 - 2050). Fuente: Naciones Unidas, World Population Prospects: The 2002 Revision (escenario medio), 2003 (3).

Figure 1. World population growth in "developing" and "'eveloped" regions (1950 - 2050). Source: United Nations, World Population Prospects: The 2002 Revision (average scenario), 2003 (3).

\section{Cuantificación del déficit universal de viviendas}

A comienzos del presente siglo XXI se estimó en 100 millones, mayoritariamente ancianos y niños, las personas urbanas que no contaban con ningún tipo de cobijo, los llamados "sin techo"1. Por otra parte, para atender a los nuevos hogares que se formarán, se requerirán según Naciones Unidas (5) unos 22 millones de viviendas anuales en los tres primeros lustros del presente siglo y 27 millones anuales en los siguientes 15 años, si se tienen en cuenta necesidades de reposición causadas por desastres naturales y desalojos forzados (ver Tabla 1).

La Tabla 1 permite constatar que si bien es cierto que el mayor desafío cuantitativo se presenta en Asia, es en

1 El Centro Internacional para el Derecho a la Vivienda y contra los Desalojos, COHRE, estima que unos 100 millones de personas carecen de albergue de cualquier tipo para pasar la noche, sin contabilizar los 2.000 millones de personas que viven en condiciones precarias (4).

\section{Quantification of the universal housing deficit}

At the dawn of the 21st century, an estimated 100 million city dwellers, primarily children and elderly adults, had no type of shelter, swelling the ranks of the so-called "homeless"1. Moreover, according to the United Nations (5), around 22 million dwellings will be needed yearly for new families in the first fifteen years of the present century and 27 million in the following 15, account taken of the replacement needs resulting from natural disasters and evictions (see Table 1).

Table 1 shows that while the quantitatively largest challenge is located in Asia, urbanization and precarious

1 El The Centre on Housing Rights and Evictions, COHRE, estimates that some 100 million people have no shelter whatsoever in which to spend the night, not to mention the 2.000 billion people who live in precarious conditions (4). 
Tabla 1 / Table 1

Necesidades anuales de nuevas viviendas urbanas, de 2000 a 2030. New urban dwellings: annual needs, 2000 to 2030.

\begin{tabular}{|l|c|c|}
\hline Continentes / Continent & $\begin{array}{c}\text { Años 2000 a 2015 } \\
\text { (En miles de viviendas) } \\
\text { Years 2000 to 2015 } \\
\text { (In thousands of dwellings) }\end{array}$ & $\begin{array}{c}\text { Años 2015 a 2030 } \\
\text { (En miles de viviendas) } \\
\text { Years 2015 to 2030 } \\
\text { (In thousands of dwellings }\end{array}$ \\
\hline África & 3.941 & 6.169 \\
\hline Asia & 14.513 & 18.043 \\
\hline $\begin{array}{l}\text { América Latina y Caribe } \\
\text { Latin America And The Caribbean }\end{array}$ & 3.081 & 3.113 \\
\hline Total De Los Tres Continentes / Total & 21.535 & 27.325 \\
\hline
\end{tabular}

Nota: Estimaciones sobre la base del aumento probable de hogares urbanos. Fuente: UN -HABITAT (1996), Anexo Estadístico del Informe Anual (5). Note: Estimates based on the expected growth of urban dwellings. Source UN -HABITAT (1996), Annual Report, Statistical Annex (5).

África donde acontece el proceso más rápido de urbanización y de crecimiento de la precariedad urbana. Coincidimos con Mac Donald (6) al afirmar que, de los tres continentes de la Tabla 1, Latinoamérica es el que presenta el panorama habitacional más manejable.

\section{La tugurización creciente}

No resulta fácil encontrar datos contrastables sobre la situación del hábitat de los más pobres, menos aún en las áreas rurales, por ello, son significativos los que aporta la Tabla 2, en la que destaca el dato de población urbana "tugurizada" que en 2001 se fijó en 924 millones de per- urban living are growing fastest in Africa. MacDonald (6) claims that the housing scenario is more manageable in Latin America than in the other two continents shown in Table 1, a judgement shared by the authors of the present paper.

\section{Growing "slumization"}

In light of the scant availability of verifiable data on the housing situation among the poorest of the poor, particularly in rural areas, the figures in Table 2 are significant, especially as regards the number of people living in urban slums, estimated in 2001 to be 924 million or

Tabla 2 / Table 2

Población viviendo en tugurios (Estimaciones de UN HABITAT, 2001).

Population living in slums (UN-HABITAT, 2001 estimates).

\begin{tabular}{|l|c|c|c|c|c|}
\hline \multicolumn{1}{|c|}{$\begin{array}{c}\text { Áreas de estudio } \\
\text { Area }\end{array}$} & $\begin{array}{c}\text { Población total } \\
\text { (en millones) } \\
\text { Total population } \\
\text { (in millions) }\end{array}$ & $\begin{array}{c}\text { Población urbana (total } \\
\text { en millones y en \%) } \\
\text { Urban population (total } \\
\text { in millions \& in \%) }\end{array}$ & $\begin{array}{c}\text { Población en tugurios } \\
\text { urbanos (total en } \\
\text { millones) } \\
\text { Population in urban } \\
\text { slums (total in } \\
\text { millions) }\end{array}$ & $\begin{array}{c}\text { \% deblación } \\
\text { urbana } \\
\text { en tugurios } \\
\text { \% of urban } \\
\text { population in } \\
\text { slums }\end{array}$ \\
\hline Años / Years & $\mathbf{2 0 0 1}$ & $\mathbf{2 0 0 1}$ & $\mathbf{2 0 0 1}$ & $\mathbf{2 0 0 1}$ & $\mathbf{2 0 0 1}$ \\
\hline $\begin{array}{l}\text { Mundo (total) } \\
\text { World (total) }\end{array}$ & 6.134 & 2.923 & 43,5 & 924 & 31,6 \\
\hline $\begin{array}{l}\text { Regiones desarrolladas (MD) } \\
\text { Developed regions (DW) }\end{array}$ & 1.194 & 902 & 73,7 & 54 & 5,9 \\
\hline $\begin{array}{l}\text { Regiones en vías de } \\
\text { desarrollo (PVD) } \\
\text { Developing regions (DC) }\end{array}$ & 4.940 & 2.022 & 35,0 & 870 & 43,0 \\
\hline $\begin{array}{l}\text { Países menos desarrollados } \\
\text { Least developed countries }\end{array}$ & 685 & 179 & 20,8 & 140 & 78,2 \\
\hline $\begin{array}{l}\text { Norte de África } \\
\text { North Africa }\end{array}$ & 76 & & & 21 & \\
\hline $\begin{array}{l}\text { Países sub-saharianos } \\
\text { Sub-Saharan countries }\end{array}$ & 231 & & & & \\
\hline
\end{tabular}

Fuente: Improving the lives of 100 million slum dwellers, Global Observatory, UN-HABITAT, Nairobi, 2003, (7). Source: Improving the lives of 100 million slum dwellers, Global Observatory, UN-HABITAT, Nairobi, 2003, (7). 
sonas, lo que suponía el $31,6 \%$ de la población urbana mundial y que llegaba hasta el $78,2 \%$ en los países menos desarrollados.

Los tugurios son considerados por algunos gobiernos de PVD como 'un problema', mientras que para sus habitantes y los sectores que los apoyan son la única solución posible para acceder a la tierra y la vivienda. Desafortunadamente, la práctica demuestra que, aparentemente, para reducir de forma momentánea la población en tugurios de los países africanos, se está recurriendo al desalojo forzado y la exclusión (8).

Los programas de mejora y rehabilitación de tugurios ganan adeptos por su pertinencia como herramienta de lucha contra la pobreza e impulso para sentar bases de desarrollo productivo. Los llamados 'Objetivos del Milenio' fijan en su Meta 11 objetivo 7: mejorar sustancialmente, antes de 2020, las condiciones de vida de por lo menos 100 millones de personas alojadas en tugurios. Ello supone un reto prácticamente imposible de conseguir sin la industria, pero absolutamente inabordable sin la participación real de los pobladores. La convergencia entre la participación ciudadana y el concurso de la industria lleva a la necesidad ineludible de perfilar nuevos enfoques de futuro (9).

\section{2. "Bajo coste" y "vivienda mínima"}

No es factible acotar de forma global que entender por 'bajo coste' de construcción de una vivienda, entre otras razones, por la imposibilidad de llegar a consensos universales sobre lo que es o no una 'vivienda mínima'. Ambos aspectos: costo y prestaciones, son variables muy cambiantes según países, tipologías, niveles económicos, tipos de promotores... lo que lleva a proponer seguidamente algunas acotaciones que no pueden ser ni absolutas ni universales, y por tanto, necesariamente cambiantes según países y circunstancias. ¿Cómo formular una respuesta aceptable en una controversia tan dispar? Se propone su relativización mediante la adopción de un patrón único de medida que permita una lógica comparativa: el salario mínimo mensual oficial interprofesional, que puede que sea el patrón de comparación más operativo, aunque, lógicamente, no exento de problemas.

Sin otro referente de legitimación que la práctica de los autores, se adopta como 'bajo coste' por metro cuadrado de superficie construida, valores situados entre dos y tres salarios mínimos mensuales. Por otra parte, en lo relativo al dimensionado de la superficie, las propuestas de 'vivienda mínima' suelen oscilar entre 25 y $30 \mathrm{~m}^{2}$ construidos, relativos a la primera etapa, de la unidad de vivienda semilla, de crecimiento posterior progresivo.

Las anteriores propuestas, aunque limitan posibles variaciones del 'bajo coste' y de la 'vivienda mínima', suponen
$31.6 \%$ of the world population. Up to $78.2 \%$ of the population in the least developed countries live in such environments.

Slums are regarded by some DC governments to be "a problem", while for their inhabitants and the sectors supporting them they are the only possible way to access land and a dwelling. Unfortunately, evidence shows that to momentarily reduce slum populations in African countries, some authorities are apparently resorting to eviction and exclusion (8).

Slum improvement and rehabilitation programmes are gaining followers as a tool in the struggle against poverty and a driver of productive development. One of the targets of UN Millennium Goal 11 Target 7 is: to achieve significant improvement in lives of at least 100 million slum dwellers, by 2020. This aim is practically impossible to meet without industry involvement, but it is absolutely unfeasible without the participation of the settlers themselves. The convergence between citizen participation and a commitment on the part of industry leads to the inescapable need to define a new focus for the future (9).

\section{2. "Low cost" and "minimum dwelling"}

No globally accepted definition can be given for "low cost" housing construction, among other reasons because there is no universal consensus on what is or is not a "minimum dwelling". Both aspects, cost and features, vary widely depending on the country, typology, standard of living and type of developer... all of which leads to proposals for delimitations that can be neither absolute nor universal and necessarily change depending on the country and the circumstances. How can an acceptable solution be found for a controversy characterized by such widely ranging opinions? The present article proposes the use of a relative measure on which comparative analysis can be based: minimum wage, perhaps the most operational grounds for comparison, but obviously not without its problems.

With little else to go on than the authors' own practice, "low cost" per square metre of built area is defined to be the salary earned by a minimum wage worker in two to three months' time. The proposals for the area of "minimum dwellings", in turn, tend to range from 25 to $30 \mathrm{~m}^{2}$ of built area in the first stage or core dwelling, to which successive additions are expected to be attached.

While the above proposals limit possible variations on what constitutes "low cost" and "minimum dwelling", 
de por sí márgenes amplios que se moverían entre 50 y 90 salarios mínimos por solución habitacional2 construida. La propuesta se abre a una traducción práctica según países y circunstancias que oscilaría, por ejemplo, entre 5.000 y 9.000 \$USA en el caso de San Salvador (El Salvador, Centroamérica) y entre 2.500 y 4.500 \$USA en Maputo (Mozambique, África).

Pese a la importancia de referir, a efectos de acotar su coste de construcción y nivel de calidad, la "vivienda mínima" al número de salarios mínimos mensuales, se sugiere también, como su patrón de medida más universal y representativo, el precio de mercado del saco de cemento -pues puede que sea la unidad de referencia más homogénea del sector construcción-, de cuyo empleo resultan algunas conclusiones sumamente impactantes.

Hace algo más de dos décadas, el 'Informe de Conclusiones de la Primera Consulta sobre la Industria de los Materiales de Construcción', organizada por Naciones Unidas para el Desarrollo Industrial (10), presentaba (ver Figura 2) la equivalencia, en ese momento, 1985, entre el salario mínimo interprofesional por día de trabajo y el número de sacos de cemento o de placas onduladas de cubierta que se podían adquirir con el mismo. El resultado era: diez bolsas o sacos de $50 \mathrm{~kg}$ para un obrero industrial escandinavo; una para un trabajador urbano centroamericano y un décimo de bolsa para un empleado agrícola del Este de África. Hoy, veintitrés años después, puede afirmarse que las proporciones se mantienen prácticamente idénticas si se aceptan como salarios mínimos interprofesionales los 1.200 \$USA / mes de Suecia, los 150 \$USA / mes en el sector industrial de Honduras y los escasos 60 \$USA / mes de un empleado rural de Mozambique; con precios de la tonelada de cemento que oscilan, a su vez, entre 170 \$USA en Suecia, 120 en Tegucigalpa y hasta 250 en Chokwe -población rural de Mozambique-, respectivamente, lo que traducido a número de bolsas de $50 \mathrm{~kg}$ de cemento equivale a una capacidad adquisitiva mensual de: $141 ; 21$ y 4,8 bolsas, respectivamente. De estas abultadas diferencias pueden deducirse, cuando menos, tres conclusiones parciales:

1.- Que la industria cementera ha evolucionado poco en el ratio prestaciones / precios de mercado (lo que supone una excepción entre los sectores productivos industriales tradicionales);

2.- Que los técnicos en los PVD deberían asignar al cemento, según los contextos de su utilización, un empleo de

2 Se asume internacionalmente como solución habitacional, lo que en castellano puede nominarse como cobijo precario, aún a sabiendas de que no es una vivienda acabada, ni por superficie, ni por calidades, prestaciones, seguridad, etc. they establish ample margins that would fluctuate from 50 to 90 months' minimum wage earnings per dwelling solution built2. The actual cost would vary by country and circumstances, ranging, for instance, from US $\$ 5,000$ to US $\$ 9,000$ in a Central American city (San Salvador in El Salvador) and from US $\$ 2,500$ to US $\$ 4,500$ in an African capital (Maputo, Mozambique.

But the importance of defining the construction costs and quality of a "minimum dwelling" in terms of the number of monthly minimum wage salaries is that the approach can be adopted for its component parts, such as the price of a bag of cement, the most universal and representative (and perhaps the most standardized) unit of measure in construction. The use of this unit leads to a number of particularly significant conclusions.

A little over two decades ago, the "First Consultation on Building Material" organized by the United Nations Industrial Development Organization (10) (see Figure 2) calculated the number of bags of cement or corrugated roofing panels that could be bought at the time (1985) with the minimum daily wage. The result was: for a Scandinavian industrial worker, ten $50-\mathrm{kg}$ bags of cement; for a Central American urban worker, one bag; and for a farmhand in Eastern Africa, one tenth of a bag. Today, twenty three years later, these proportions can be said to remain practically the same, assuming the minimum monthly wage to be US \$1,200 in Sweden, US \$150 in the industrial sector in Honduras and barely US $\$ 60$ for farmhands in Mozambique, and the price of a tonne of cement, US \$170 in Sweden, US \$120 in Tegucigalpa and up to US \$250 in Chokwe, a rural town in Mozambique. Expressed in 50-kg bags of cement, this amounts to a monthly purchasing power of 141, 21 and 4.8 bags, respectively. At least three partial conclusions can be drawn from these huge differences:

1.- The value/market price ratio has varied very little in the cement industry (constituting an exception among traditional industries);

2.- Depending on the context and use, architects and engineers in DCs should give cement a greater struc-

2 Internationally assumed to be a dwelling solution, in the realization that it is unfinished housing in terms of area, quality of materials, features, safety and so on. 
mayor responsabilidad estructural y de diseño mejor ajustado que los que se le otorgan en la actualidad; especialmente en los casos de viviendas de una planta en zonas no sometidas a actividad sísmica;

3.- Que no se cumple la lúcida definición de Ortega (11) al acotar que: "La técnica es el esfuerzo para ahorrar esfuerzo. Es un esfuerzo mucho menor con el que, a la larga evitamos un esfuerzo mucho mayor... Ese afán de ahorrar esfuerzo y, por tanto, de poder llegar a hacer real la vida buena, es lo que impulsa la técnica". tural role and more accurate design than at present, especially in one-storey housing in non-seismic areas;

3.- Practice is not compliant with Ortega's (11) lucid definition to the effect that: "Technology is the effort to save effort. It is a minor effort that saves much greater effort in the long run... That desire to save effort and consequently to make life easier is what drives technological development".

OBRERO ESCANDINAVO / SCANDINAVIAN WORKER
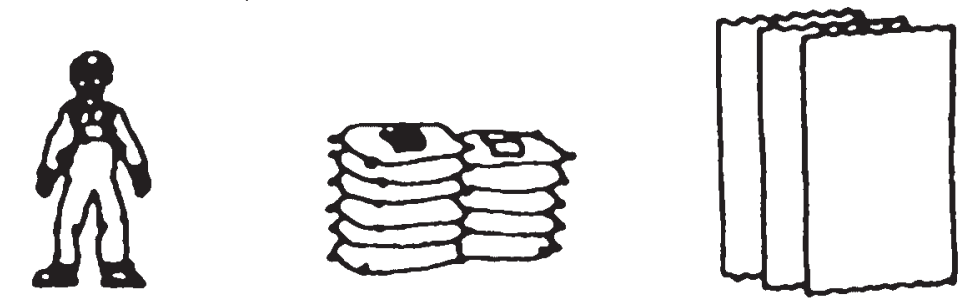

SALARIO DE UN DÍA $=10$ SACOS DE CEMENTO $=3$ PLACAS DE CUBIERTA DAILYWAGE $=10$ BAGS OF CEMENT = 3 ROOF PANEL

CENTRO AMÉRICA (URBANO) / CENTRAL AMERICA (URBAN)

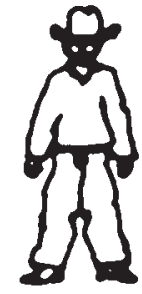

SALARIO DE UN DÍA $=1$ SACO DE CEMENTO DAILY WAGE

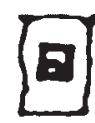

1 BAG OF CEMENT

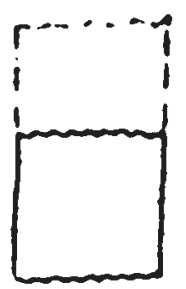

$=1 / 2$ PLACAS DE CUBIERTA $=\quad 1 / 2$ ROOF PANEL

ESTE DE ÁFRICA (RURAL) / EAST AFRICA (RURAL)

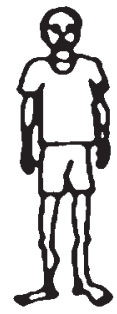

SALARIO DE UN DÍA DAILY WAGE

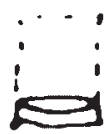

1/10 SACOS DE CEMENTO 1/10 BAGS OF CEMENT

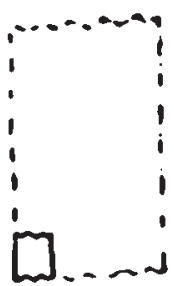

1/24 PLACAS DE CUBIERTA 1/24 ROOF PANEL

Figura 2. Reproducción de una diapositiva de la presentación aludida de ONUDI en 1985 (10).

Figure 2. Reproduction of a slide presented at a 1985 UNIDO meeting (10). 


\section{GRANDES RETOS PARA LA INDUSTRIA DE MATERIALES BÁSICOS DE CONSTRUCCIÓN}

\subsection{Desglose de costes de edificación: cuatro rea- lizaciones latinoamericanas 3}

La repercusión del coste de los materiales en el total de la vivienda es extraordinariamente variable según circunstancias y contextos. Acotar esta constatación lleva a los autores a presentar seguidamente la descomposición de costes de construcción de cuatro realizaciones en otros tantos países: Colombia, Brasil, Chile y El Salvador. Cuatro realizaciones diferentes con algunas características importantes en común:

Se trata en los cuatro casos, de realizaciones: entre 100 y 200 viviendas; de 45 a $60 \mathrm{~m}^{2}$ construidos por vivienda; de promoción privada; construidas entre los años 1995 y 2000; situadas ${ }^{4}$ en Zipaquirá (Colombia), Bello Horizonte (Brasil), Rancagua (Chile) y San Salvador (El Salvador) ${ }^{5}$.

Pese a que no hay dos realizaciones idénticas, máxime tratándose de tipologías de viviendas distintas en países diferentes, en los que hasta la distribución y terminología de los capítulos del presupuesto cambian, la comparación que sigue proporciona algunas enseñanzas generales fáciles de obtener por haber tenido los autores acceso directo a las cuatro realizaciones, lo que permitió, a su vez, poder establecer en forma homogénea, para su cotejo, los desgloses de precios que recoge la Tabla 3.

3 Aún conscientes de que el trabajo pretende una panorámica universalista, la falta de resultados de trabajos fiables en estos temas, lleva a ceñir algunos aspectos al campo exclusivo de América Latina, más cercano a la práctica profesional de los autores. Se llama la atención al respecto que en modo alguno se presuponen válidas posibles extrapolaciones de los resultados que siguen ni a la totalidad del continente latinoamericano y mucho menos a los casos de Asia o África.

4 En el primer caso se trataba de 165 viviendas adosadas de dos plantas, de $64 \mathrm{~m}^{2}$ construidos en parcelas de $84 \mathrm{~m}^{2}$ realizadas por la empresa Ítaca en 1999, con un precio de construcción aproximado de 221 \$USA por $\mathrm{m}^{2}$ (12). En el caso de la realización en Bello Horizonte se trató de 124 viviendas de una planta de $36 \mathrm{~m}^{2}$ que resultaron a un coste de 254 \$USA / m² (13). La realización en Rancagua (Chile) la conforman 208 viviendas unifamiliares de 57,27 $\mathrm{m}^{2}$ cada una en parcelas de $105 \mathrm{~m}^{2}$ (14). La cuarta y última de las realizaciones que se comparan, ejecutada en San Salvador, la conforman 93 viviendas de $32,5 \mathrm{~m}^{2}$ en parcelas de $55 \mathrm{~m}^{2}$ cuyos costos indirectos comprenden el diseño del proyecto, el coste financiero de las obras y los costes de gestión y administración. El precio aproximado fue de 250 \$USA / $\mathrm{m}^{2}$ (15).

5 En modo alguno pueden considerarse estos cuatro casos como "media" de Latinoamérica, pero si representa una muestra centrada si se tienen en cuenta los Índices de Desarrollo Humano que detentan los cuatro países en los que se ejecutaron conforme a la clasificación anual del PNUD. En el listado de 2002, sobre 173 países evaluados, los países elegidos ocupaban las siguientes posiciones: Colombia ( $\left.n^{\circ} 68\right)$; Brasil ( $n^{\circ}$ 73); Chile ( $\left.n^{\circ} 38\right)$ y El Salvador ( $\left.n^{\circ} 104\right)$.

\section{MAJOR CHALLENGES FACING THE BASIC CONSTRUCTION MATERIALS INDUSTRY}

\subsection{Breakdown of building costs: four latin ameri- can developments ${ }^{3}$}

The impact of materials on total housing construction costs is extraordinarily variable and depends on circumstances and contexts. This claim is substantiated by the itemization of construction costs in four social housing developments, one each in Colombia, Brazil, Chile and El Salvador. While different, these four projects nevertheless shared some common characteristics:

In all four cases the developments: comprised from 100 to 200 privately developed 45- to $60-\mathrm{m}^{2}$ dwellings, built between 1995 and 2000 and located4 in Zipaquirá, Colombia; Bello Horizonte, Brazil; Rancagua, Chile and San Salvador, El Salvador5.

Even though no two developments were alike, with differences not only in typologies and countries but even in the structure and terminology of the chapters of the budget, some general lessons can be learnt from the following comparison. Based on data to which the authors had direct access, Table 3 shows the standardized price breakdowns for the four developments.

3 While aware that the paper aims to provide a universal overview, the lack of reliable studies on the subject has led to restricting certain aspects to Latin America, a region nearer to the authors' own professional practice. Attention is drawn to the fact that these findings may not be extrapolated to the entire Latin American continent, or, naturally, to Asia or Africa.

4 In the first case, the development consisted in 165 twostorey attached units with an area of $64 \mathrm{~m}^{2}$ each, built on 84- $\mathrm{m}^{2}$ lots by Ítaca in 1999 at an approximate construction cost of US $\$ 221$ per $m^{2}$ (12). The Bello Horizonte development has 124 one-storey, 36- $m^{2}$ units, built at a cost of US $\$ 254$ per $m^{2}$ (13). The Rancagua development in Chile comprised 206, 57.27- $\mathrm{m}^{2}$ single family units, each on 105- $\mathrm{m}^{2}$ lots (14). The fourth and last of the developments compared, built in San Salvador, consisted in 93, 32.5- $\mathrm{m}^{2}$ housing units on 55- $\mathrm{m}^{2}$ lots whose overhead costs included design, financing, and management and administration. The price came to approximately US $\$ 250$ per $m^{2}$ (15).

5 These four developments cannot by any means be regarded to be an "average" for Latin America, but they do constitute a focused sample, in light of the PNUD Human Development Indices for the four countries where they were built. Of the 173 countries assessed in the 2002 listing, the countries studied here were ranked as follows: Colombia, 68; Brazil, 73; Chile, 38; and El Salvador, 104. 
Tabla 3 / Table 3

Descomposición porcentual de precios de cuatro realizaciones de viviendas sociales en Colombia, Brasil, Chile y El Salvador (en dólares USA de 1999).

Cost breakdown (in per cent) for social housing in Colombia, Brazil, Chile and El Salvador (in USD at 1999 exchange rate).

\begin{tabular}{|c|c|c|c|c|c|c|c|c|c|c|c|c|}
\hline \multirow[b]{2}{*}{$\begin{array}{l}\text { Capítulos de precios } \\
\text { Cost category }\end{array}$} & \multicolumn{3}{|c|}{$\begin{array}{l}\text { (a) ZIPAQUIRÁ } \\
\text { (COLOMBIA) }\end{array}$} & \multicolumn{3}{|c|}{$\begin{array}{l}\text { (b) BELO ORIZONTE } \\
\text { (BRASIL) }\end{array}$} & \multicolumn{3}{|c|}{$\begin{array}{l}\text { (c) RANCAGUA } \\
\text { (CHILE) }\end{array}$} & \multicolumn{3}{|c|}{$\begin{array}{l}\text { (d) SAN SALVADOR } \\
\text { (EL SALVADOR) }\end{array}$} \\
\hline & $\begin{array}{c}\text { Costo } \\
\text { Total } \\
\text { Total } \\
\text { Final } \\
\text { Cost }\end{array}$ & $\%$ & $\begin{array}{c}\text { Costo } \\
\mathbf{m}^{2} \\
\text { Cost } \\
\boldsymbol{m}^{2}\end{array}$ & $\begin{array}{c}\text { Costo } \\
\text { Total } \\
\text { Total } \\
\text { Cost }\end{array}$ & $\%$ & $\begin{array}{c}\text { Costo } \\
\mathbf{m}^{2} \\
\text { Cost } \\
m^{2}\end{array}$ & $\begin{array}{c}\text { Costo } \\
\text { Total } \\
\text { Total } \\
\text { Cost }\end{array}$ & $\%$ & 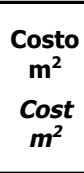 & $\begin{array}{c}\text { Costo } \\
\text { Total } \\
\text { Total } \\
\text { Cost }\end{array}$ & $\%$ & $\begin{array}{c}\begin{array}{c}\text { Costo } \\
\mathbf{m}^{2}\end{array} \\
\text { Cost } \\
m^{2}\end{array}$ \\
\hline $\begin{array}{l}\text { Terreno } \\
\text { Land }\end{array}$ & 1332 & 9,40 & 20,81 & 620,0 & 7,0 & 17,2 & 989,2 & 9,2 & 17,3 & 675,95 & 8,3 & 20,8 \\
\hline $\begin{array}{l}\text { Urbanización } \\
\text { Urbanization }\end{array}$ & 1435 & 10,13 & 22.4 & 553,4 & 29,0 & 70,9 & $1.655,9$ & 15,4 & 28,9 & $1.920,0$ & 26,9 & 59,0 \\
\hline $\begin{array}{l}\text { Construcción } \\
\text { Construction }\end{array}$ & 6779 & 47,85 & 105,9 & $4.699,3$ & 53,3 & 130,5 & $6.726,5$ & 62,8 & 117,4 & $3.311,3$ & 46,4 & 102,0 \\
\hline $\begin{array}{l}\text { Costes indirectos: beneficios, } \\
\text { gestión y administración, } \\
\text { proyecto... } \\
\text { Indirect costs: profit, } \\
\text { management and } \\
\text { administration, design... }\end{array}$ & 4621 & 32,62 & 72,2 & 947,3 & 10,7 & 26,3 & 1332,3 & 12,44 & 23,2 & 2255,2 & 27,5 & 68,6 \\
\hline $\begin{array}{l}\text { PRECIOS TOTALES } \\
\text { TOTAL }\end{array}$ & 14.167 & 100,00 & 221,4 & $8.820,0$ & 100,0 & 254,0 & $10.711,0$ & 100,0 & 187,0 & $8.136,6$ & 100,0 & 250,3 \\
\hline
\end{tabular}

Fuente: los autores sobre los datos referenciados en nota al pié de página.

Source: prepared for this paper from authors information as specified in the text.

En la Tabla 3 pueden apreciarse variaciones en los costes de construcción por metro cuadrado construido que oscilan entre: 105,9; 130,5; 117,4 y 102,0 \$USA, respectivamente, y en la Figura 3 se recogen los valores porcentuales medios de los cuatro casos y los de las medias de la muestra; entre los que destaca el 52,59\% correspondiente a la media del capítulo "construcción", es decir, la materialización de la vivienda propiamente dicha. Para
The variations in total building costs per square metre of built area given in Table 3 are as follows: US \$105.9, US $\$ 130.5$, US \$117.4 and US \$102.0. Figure 3, in turn, shows the mean percentages of the various cost categories for each of the developments and for the sample as a whole, in which "construction" or the materialization of the housing per se, accounts for $52.59 \%$ of the total. To

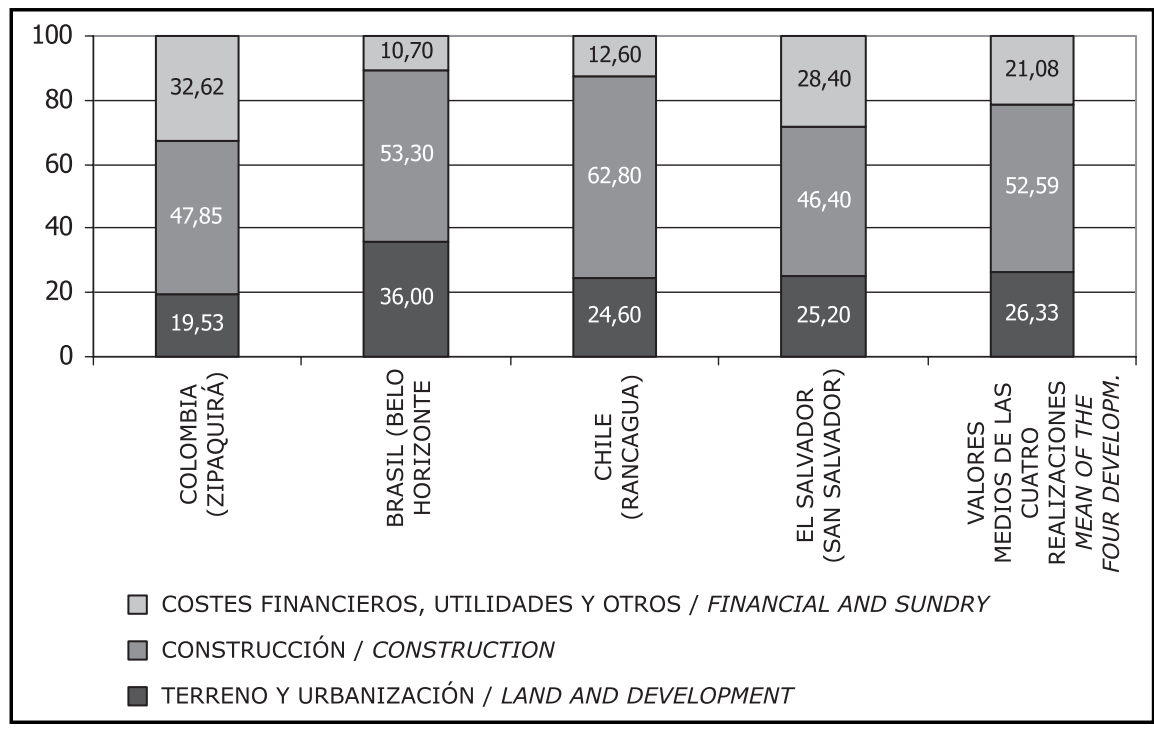

Figura 3. Descomposición porcentual de precios de las cuatro realizaciones latinoamericanas. Fuente: los autores sobre las bases mencionadas en el texto. Figura elaborada para este trabajo.

Figure 3. Percentage breakdown of costs in four latin american developments.

Source: prepared for this paper from authors information as specified in the text. 
facilitar posteriores comparaciones, la Figura 3 agrupa los resultados arrojados por los cuatro casos mencionados bajo tres tipos de costes:

1.- Terreno y urbanización.

2.- Construcción (vivienda).

3.- Costes financieros, utilidades y otros.

Conforme a los resultados de los valores medios de los cuatro casos, se ha realizado la Figura 4. Los valores porcentuales de la primera columna corresponderían a países del mundo desarrollado (MD) - caso concreto de las poblaciones del Sur de Madrid- que presentan también una descomposición, aproximada, de las tres partidas de coste. En el caso de la columna tercera correspondiente a los "Países menos desarrollados", los datos adoptados no tienen más justificación que la experiencia de los autores en proyectos de cooperación para el desarrollo. facilitate subsequent comparison, Figure 3 groups the costs under three headings:

\section{1.- Land purchase and development. \\ 2.- Construction (housing). \\ 3.- Financing and sundry.}

The mean values for the four developments were used do build the graph in Figure 4. In the first column, which refers to developed world (DW) countries, the percentagesgiven for the above three items are an approximation of the situation prevailing in suburbs south of Madrid. The figures shown in the third column, headed "Least developed countries", are based merely on the authors' experience in development cooperation projects.

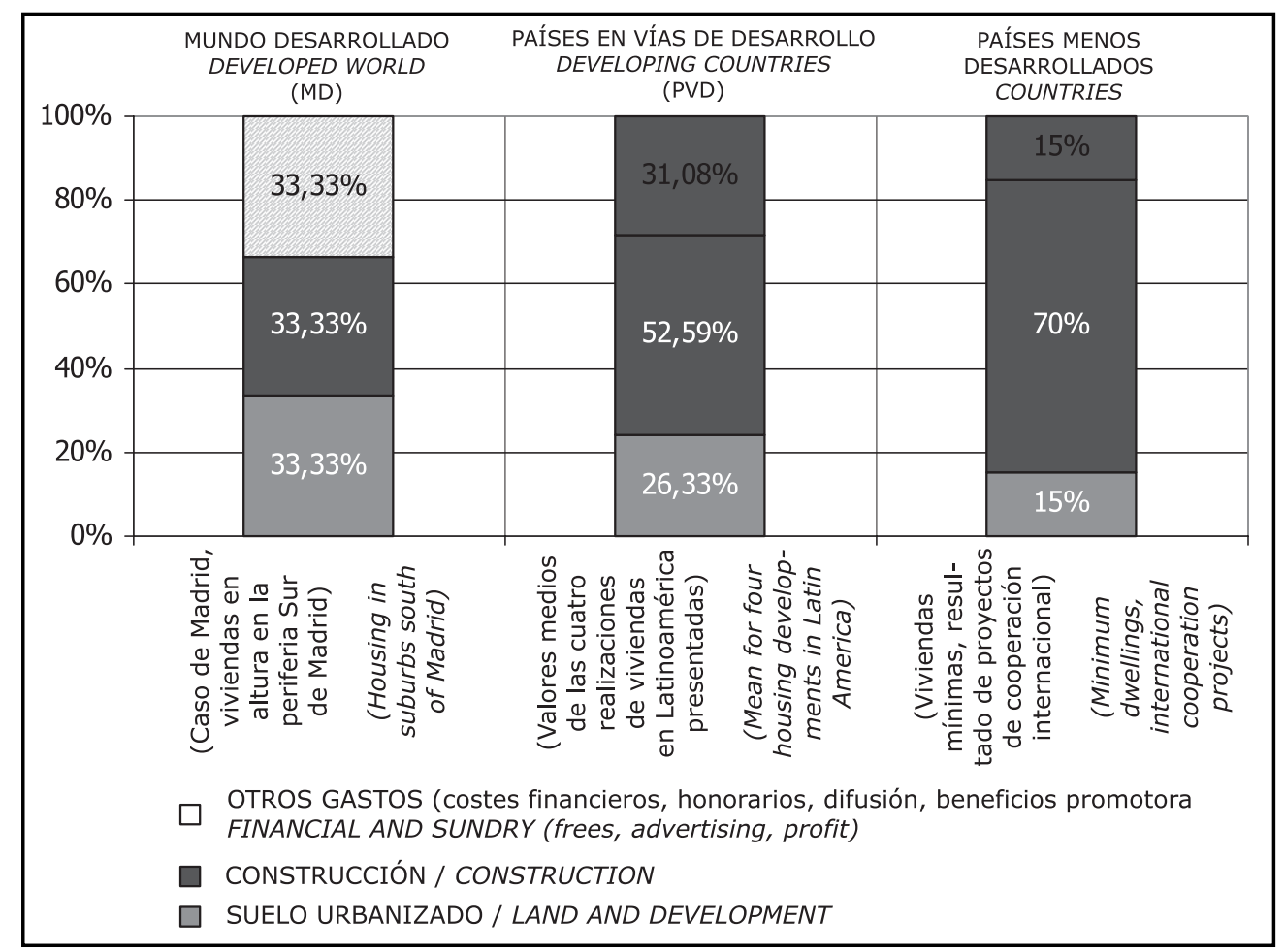

Figura 4. Ejercicio de aproximación a la cuantificación de la repercusión del coste de construcción en el precio final de lo construido en tres supùestos muy diferentes.

Fuente: los autores sobre las bases mencionadas en el texto. Figura elaborada para este trabajo.

Figure 4. Impact of building cost on final cost of housing in three different contexts Source: prepared for this paper from authors information as specified in the text.

Los valores de la Tabla 4 son resultado de estimaciones propias al descomponer la repercusión de la partida "construcción" en: "materiales", "mano de obra" y "otros", para las que se han concluido las siguientes proporciones: $2 / 5,2 / 5$ y $1 / 5$ para los casos del MD; $3 / 5,1 / 5$ y $1 / 5$
The values in Table 4 are the authors' estimates of the breakdown of "construction" costs into "materials", "labour" and "other", which came to: 2/5, 2/5 and 1/5 for the DW; 3/5, 1/5 and $1 / 5$ for DCs and 7.0/10, 1.5/10 and $1.5 / 10$ for the "least developed countries". In keeping 
para PVD; y 7,0/10, 1,5/10 y $1,5 / 10$ para 'países menos desarrollados'. Conforme con lo anterior, se deduce que la repercusión del capítulo "Materias primas, materiales elaborados, componentes y subsistemas" presenta valores extremadamente diferenciados: $13,32 \%, 31,55 \%$ y $49,00 \%$ en los casos escogidos.

En forma muy concisa y a modo de conclusiones prácticas puede afirmarse que:

- La repercusión porcentual del capítulo "Construcción" en el coste final de la obra es mayor cuanto menor es su presupuesto (Tabla 4).

- La repercusión porcentual del capítulo "Materiales" en el coste final de construcción también aumenta cuanto menor es el presupuesto total y el contexto en el que se realice, llegando a valores extremadamente dispares: $13,32 \% ; 31,55 \%$ y $49,00 \%$ respectivamente. with the above, the chapter "Raw and processed materials, components and subsystems" accounts for widely varying proportions of the total: $13,32 \%, 31,55 \%$ and $49,00 \%$ in the three cases chosen.

In a nutshell, the practical conclusions that can be drawn are:

- The smaller the overall cost, the greater is the percentage of the "construction" category (Table 4).

- Similarly, "materials" account for a higher percentage of the total construction costs in smaller overall budgets, with values fluctuating widely in the three examples: $13.32 \%, 31.55 \%$ and $49.00 \%$ in the DW, DCs and least developed countries, respectively.

Tabla 4 / Table 4

Cuantificación de la repercusión en el coste de construcción de los materiales en los tres supuestos estudiados. Impact of materials on building costs in three country types.

\begin{tabular}{|c|c|c|c|c|c|c|}
\hline \multirow{2}{*}{$\begin{array}{l}\text { DESCOMPOSICIÓN ESTIMADA DEL } \\
\text { COSTE DE CONSTRUCCIÓN EN LOS } \\
\text { SIGUIENTES CAPÍTULOS / COST } \\
\text { CATEGORY }\end{array}$} & \multicolumn{2}{|c|}{$\begin{array}{l}\text { MUNDO DESARROLLADO } \\
\text { (MD) / DEVELOPED } \\
\text { WORLD (DW) } \\
\text { (Caso de Madrid, } \\
\text { viviendas en altura en la } \\
\text { periferia Sur de Madrid) / } \\
\text { (Housing in suburbs sout } \\
\text { of Madrid) }\end{array}$} & \multicolumn{2}{|c|}{$\begin{array}{c}\text { PAÍSES EN VÍAS DE } \\
\text { DESARROLLO (PVD) / } \\
\text { DEVELOPING COUNTRIES (DC) } \\
\text { (Valores medios de cuatro } \\
\text { realizaciones de viviendas en } \\
\text { Latinoamérica) / (Mean values } \\
\text { for four housing developments } \\
\text { in Latin America) }\end{array}$} & \multicolumn{2}{|c|}{$\begin{array}{c}\text { PAÍSES MENOS } \\
\text { DESARROLLADOS / LEAST } \\
\text { DEVELOPED COUNTRIES } \\
\text { (Viviendas mínimas, resultado } \\
\text { de proyectos de cooperación } \\
\text { internacional) / (Minimum } \\
\text { dwellings, international } \\
\text { cooperation projects) }\end{array}$} \\
\hline & $\begin{array}{l}\text { Supuesto del } \\
\text { total de } \\
\text { construcción / } \\
\text { Total } \\
\text { construction } \\
\text { assumption } \\
33,33\end{array}$ & $\begin{array}{l}\text { Repercusión } \\
\text { porcentual } \\
(\%) / \\
\text { Percentage } \\
\text { impact (\%) }\end{array}$ & $\begin{array}{l}\text { Supuesto del } \\
\text { total de } \\
\text { construcción / } \\
\text { Total } \\
\text { construction } \\
\text { assumption } \\
52,59\end{array}$ & $\begin{array}{l}\text { Repercusión } \\
\text { porcentual } \\
(\%) / \\
\text { Percentage } \\
\text { impact (\%) }\end{array}$ & $\begin{array}{l}\text { Supuesto del } \\
\text { total de } \\
\text { construcción / } \\
\text { Total } \\
\text { construction } \\
\text { assumption } \\
70,00\end{array}$ & $\begin{array}{l}\text { Repercusión } \\
\text { porcentual } \\
(\%) / \\
\text { Percentage } \\
\text { impact (\%) }\end{array}$ \\
\hline $\begin{array}{l}\text { MATERIALES: TOTAL DE MATERIAS } \\
\text { PRIMAS, MATERIALES ELABORADOS, } \\
\text { COMPONENTES, SUBSISTEMAS... } \\
\text { MATERIALS: TOTAL PRIME AND } \\
\text { PROCESSED MATERIALS, COMPONENTS, } \\
\text { SUB-SYSTEMS... } \\
\text { (Conjunto de las aportaciones físicas que } \\
\text { Ilegan a la obra en el sentido más amplio) } \\
\text { (All materials and supplies on the building } \\
\text { site) }\end{array}$ & $\begin{array}{c}2 / 5 \\
(33,33)\end{array}$ & $13,32 \%$ & 3 / $5(52,59)$ & $31,55 \%$ & $\begin{array}{r}7,0 / 10 \\
(70,00)\end{array}$ & $49,00 \%$ \\
\hline $\begin{array}{l}\text { TOTAL MANO DE OBRA } \\
\text { TOTAL LABOUR }\end{array}$ & $\begin{array}{c}2 / 5 \\
(33,33)\end{array}$ & $13,32 \%$ & $1 / 5(52,59)$ & $10,52 \%$ & $\begin{array}{l}1,5 / 10 \\
(70,00)\end{array}$ & $10,50 \%$ \\
\hline $\begin{array}{l}\text { OTROS: transporte, pérdidas, imprevistos } \\
\text { OTHERS: transportation, missing } \\
\text { materials, contingencies. }\end{array}$ & $\begin{array}{c}1 / 5 \\
(33,33)\end{array}$ & 6,66 & $1 / 5(52,59)$ & $10,52 \%$ & $\begin{array}{l}1,5 / 10 \\
(70,00)\end{array}$ & $10,50 \%$ \\
\hline TOTALES / TOTALS & & $33,33 \%$ & & $52,59 \%$ & & $70,00 \%$ \\
\hline
\end{tabular}

Fuente: los autores sobre las bases mencionadas en el texto. Tabla elaborada para este trabajo.

Source: prepared for this paper from authors information as specified in the text. 


\subsection{La producción 'formal' de materiales y el con- sumo 'informal'}

En general, la lógica de los costes de construcción en los países en desarrollo (PVD) no es reflejo de lo que ocurre en los países industrializados (MD), incluso al interior de los primeros, las diferencias entre la repercusión de los materiales en los sectores "formal" e "informal" llegan a ser extraordinarias. Los materiales importados no distinguen en los costes de producción aunque si en sus precios si se destinan o no al MD o al los PVD, todo lo contrario. H. Houben (16) cita trabajos del Banco Mundial en los que se constata que en la mayoría de los países africanos el precio del cemento para los constructores es dos y tres veces superior al pagado por el Estado, y que en el mercado 'informal' del mismo país, el precio llega a ser cuatro veces mayor.

\section{2. "Formal" and "informal" production of mate- rials}

As a rule, the pattern of construction costs in developing countries (DCs) does not mirror the situation in industrialized countries $(D W)$, and even within the latter remarkable differences are found in the "formal" and "informal" sectors with respect to the percentage of total costs attributable to materials. While imported materials are not distinguished in production costs, their price has a visible impact depending on whether their final destination is the DW or a DC. H. Houben (16) quotes World Bank reports according to which in most African countries the price of cement for builders is from two to three times higher than paid by the State, and the "informal" market price may be up to four times higher.

Tabla 5 / Table 5

Rasgos predominantes de la producción de materiales en américa latina. Characteristics of materials production in latin america.

\begin{tabular}{|c|c|c|}
\hline $\begin{array}{c}\text { TIPO DE MATERIALES Y } \\
\text { PRODUCTOS } \\
\text { MATERIAL/PRODUCT }\end{array}$ & $\begin{array}{l}\text { ESTRUCTURA SECTORIAL } \\
\text { INDUSTRY STRUCTURE }\end{array}$ & $\begin{array}{l}\text { CARACTERÍSTICAS GENERALES } \\
\text { GENERAL CHARACTERISTICS }\end{array}$ \\
\hline $\begin{array}{l}\text { - Aluminio / Aluminium } \\
\text { - Acero / Steel } \\
\text { - Vidrio / Glass } \\
\text { - Cemento / Cement }\end{array}$ & $\begin{array}{l}\text { Monopolio u oligopolio } \\
\text { concentrado / Monopoly or } \\
\text { concentrated oligopoly }\end{array}$ & $\begin{array}{l}\text { - Grandes plantas de una o pocas empresas, con alta relación } \\
\text { capital / producto. Producción homogénea. / Large, capital- } \\
\text { intensive facilities with one or more companies. Standardized } \\
\text { production. } \\
\text { - Largo período de maduración de las inversiones. / Long-term } \\
\text { investment maturity. } \\
\text { - Fuertes barreras técnicas y económicas para la entrada de } \\
\text { nuevas empresas. / High technical and economic barriers to } \\
\text { new entry. } \\
\text { - Baja sensibilidad de los precios a las variaciones de la } \\
\text { demanda. Se responde con cambios en el grado de utilización } \\
\text { de la capacidad productiva. / Prices relatively inelastic to } \\
\text { variations in demand. Response focusing on changes in use of } \\
\text { productive capacity. }\end{array}$ \\
\hline $\begin{array}{l}\text { - Fibrocemento / Fibre } \\
\text { cement } \\
\text { - Tubos plásticos / Plastic } \\
\text { pipes } \\
\text { - Tableros y planchas de } \\
\text { madera / Wood panelling }\end{array}$ & $\begin{array}{l}\text { Oligopolio relativo / Relative } \\
\text { oligopoly }\end{array}$ & $\begin{array}{l}\text { - Características similares al caso anterior, menos acentuadas. / } \\
\text { - Cimilar to preceding case, but less accentuated. } \\
\text { - Some degree of differentiation in product quality. } \\
\text { - Liderazgo de empresas grandes, con poder para establecer el } \\
\text { nivel de precios. / Large suppliers with market power. }\end{array}$ \\
\hline $\begin{array}{l}\text { - Cerámica / Clay-based } \\
\text { materials } \\
\text { - Pinturas / Paint } \\
\text { - Elementos de hormigón / } \\
\text { Concrete ele ments }\end{array}$ & $\begin{array}{l}\text { Mercado competitivo con } \\
\text { tendencia al oligopolio / } \\
\text { Competitive market tending } \\
\text { toward oligopoly }\end{array}$ & $\begin{array}{l}\text { - Plantas de tamaño mediano con relación capital / producto } \\
\text { más reducida. / Medium size, less capital-intensive facilities. } \\
\text { - Diferencias en calidad de los prod uctos. / Differences in } \\
\text { product quality. } \\
\text { - Menores barreras de entrada, más dependientes de los } \\
\text { canales de comercialización existentes. / Lower trade barriers, } \\
\text { greater dependence on existing distribution channels }\end{array}$ \\
\hline $\begin{array}{l}\text { - Madera aserrada / Sawn } \\
\text { lumber } \\
\text { - Bloques de hormigón / } \\
\text { Concrete blocks }\end{array}$ & $\begin{array}{l}\text { Mercado competitivo / } \\
\text { Competitive market }\end{array}$ & $\begin{array}{l}\text { - Predominio de empresas pequeñas y medianas. / } \\
\text { Predominance of small and medium size companies } \\
\text { - Inexistencia de barreras de entrada. Tecnología difundida. / } \\
\text { No trade barriers. Widely known technology. } \\
\text { - Importantes diferencias de calidad de los productos. / Large } \\
\text { differences in product quality } \\
\text { - Las fluctuaciones de la demanda producen efectos diversos } \\
\text { (cambios en los precios, tasas de ganancias, número de } \\
\text { empresas). / Demand fluctuations lead to changes in price, } \\
\text { profit, number of companies... }\end{array}$ \\
\hline
\end{tabular}

Fuente: José Manuel Cortínez (22). / Source: José Manuel Cortínez (22). 
Las singularidades de un mercado tan extenso como el de los materiales de construcción son extraordinariamente amplias, como puede constatarse en la Tabla 5, que se toma del trabajo de la CEPAL: Los materiales de construcción, base industrial de la producción de viviendas (17). Poco tienen en común la tecnología empleada, la estructura societaria, la forma de distribución del producto, la conformación de sus precios, etc., si se comparan las industrias del aluminio para marcos de ventanas - por ejemplo- con la de bloques de hormigón.

Dada la acentuada heterogeneidad del mercado y de la estructura productiva de los "países en desarrollo", las estrategias nacionales deberían tener más presente la actividad informal autoproductora de alojamientos, así como el segmento artesanal de producción de materiales y componente de construcción. Coincidimos con el trabajo de CEPAL cuando al referirse al sector productivo de los materiales de construcción, afirma que: "... adquieren importancia los ajustes normativos, la investigación tecnológica y la asistencia técnica encaminados a mejorar la elaboración y aplicación de materiales y técnicas regionales o locales". Hoy es perfectamente factible transferir el progreso técnico hacia este sector, con miras a obtener menores costos, mayor calidad y generar empleo calificado y mejor remunerado, mediante procesos de formalización de actividades que muestren tener potencial para un mayor desarrollo.

\section{El consumo de cemento en el sector 'informal'}

En América Latina, se intuía desde hace décadas, pero se ha cuantificado recientemente, que el consumidor mayoritario de materiales básicos de edificación es el llamado
Table 5, extracted from an ECLAC paper titled Building materials, main industrial component in housing construction (17), shows the characteristics that define the vast building materials market. Aluminium for window frames, for instance, has little in common with concrete blocks in terms of technology used, corporate structure, product distribution or pricing.

Given the extraordinary heterogeneity of market and productive structures in developing countries, national strategies should pay more heed to the informal self-construction of dwellings, as well as to the hand-crafted production of building materials and components. The ECLAC report stresses the importance in the building materials industry "...of legislative adjustments, technological research and technical assistance aiming to improve the manufacture and use of regional or local materials and techniques". It is entirely feasible today to transfer technical knowledge to this industry with a view to lowering costs, raising quality and generating skilled and better paid labour by formalizing business activities with a potential for greater development.

\section{Cement consumption in the "informal" sector}

While the Latin American "informal" sector has been known for decades to account for the largest share of basic building materials consumption (a claim that could

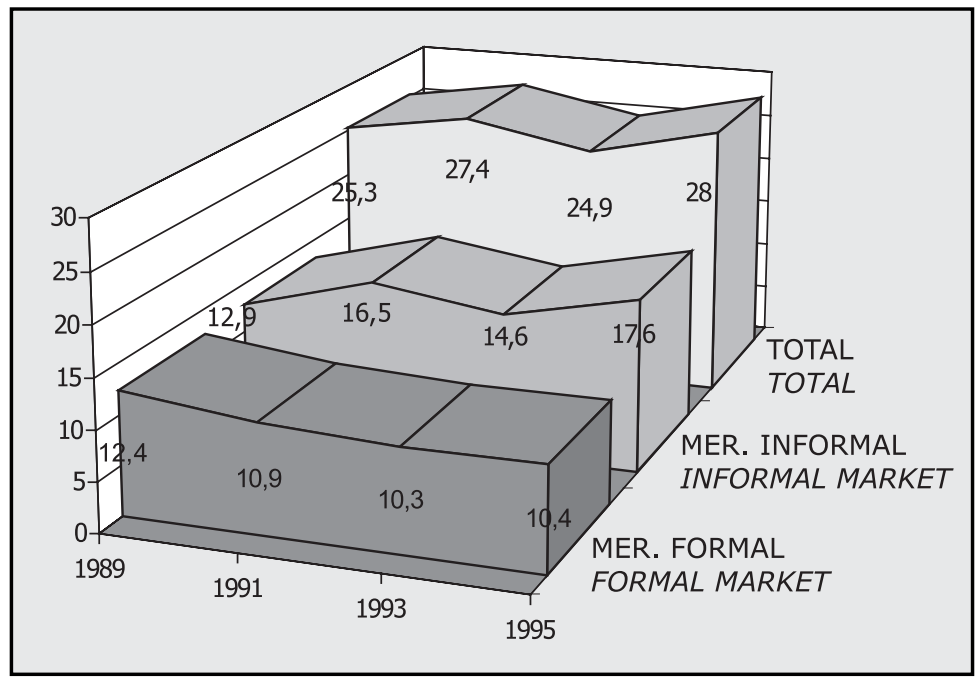

Figura 5. Ventas anuales en millones de toneladas de cemento: mercados formal, informal y total entre los años 1989 y 1995. Fuente: ABCP Associaçao Brasileira de Cimento Portland.

Figure 5. Annual cement sales, in millions of tonnes: formal and informal markets, and total amounts from 1989 to 1995. Source: ABCP Associaçao Brasileira de Cimento Portland. 
sector informal, lo que también es patente en gran parte de los PVD. Valgan como muestra los datos que aporta la Associaçâo Brasileira de Cimento Portland, ABCP (18), asegurando que desde 1989 hasta la fecha, el consumo de cemento en Brasil es siempre superior en el sector informal que en el formal y atribuye los incrementos sostenidos de ventas desde 1995, al aumento del consumidor formiga 6 que consume más del $60 \%$ del cemento producido (Ver Figura 5).

Cemex informaba en México recientemente, 2007, que "...ratifica su compromiso con la autoconstrucción ofreciendo al consumidor final productos elaborados con la más alta tecnología y calidad, lanzando al mercado su nuevo producto 'Cemento Tolteca' en presentación de bolsas de 25 kilogramos. Ello hay que enmarcarlo en el reconocimiento del crecimiento del consumo hormiga de cemento que actualmente supera el $45 \%$ del mercado cementero del país" (19). Pese al crecimiento del mercado mexicano del cemento, los responsables del sector lo consideraban como un mercado 'inmaduro' al estimar el consumo per cápita en algo más de 200 kilos por habitante / año y comprobar que el $70 \%$ del total de la producción mejicana de cemento se comercializa embolsado, lo que para Cemex ..." demuestra que la autoconstrucción es muy fuerte y nos aleja de las características del mercado de los EEUU, en el que cerca del $90 \%$ del cemento se vende a granel".

Por otra parte, en el mercado de la autoconstrucción, en el que generalmente se compra en pequeñas cantidades y se abona en el acto, en opinión del presidente de la Comisión Federal de la Competencia de México: "... el precio del cemento es entre un $20 \%$ y $25 \%$ superior al precio medio y mucho mayor que el precio para grandes consumidores que pueden pactarse como compras a futuro para períodos de más de 12 meses". El servicio de distribución al menudeo hace que las 33 plantas mexicanas de producción tengan del orden de 30.000 puntos de venta en el país, por lo que la repercusión del transporte desde la industria hasta el centro de distribución represente entre el $20 \%$ y $30 \%$ del precio de venta del saco.

El consumo de materias primas para la producción de cemento supone en peso, aproximadamente un $30 \%$ más que el del cemento producido, por lo que en España, para una producción de 38,15 MTn en el año 2000 se utilizaron del orden de 50 MTn de materias primas, mayoritariamente minerales. Dado que la producción mundial de

6 La expresión "consumo hormiga o sector hormiga" adoptada recientemente por los productores de varios países latinoamericanos, es sin duda una traducción literal del muy arraigado "sector formiga" en Brasil, que la ABCP ha contribuido a difundir con trabajos específicos de carácter cuantitativo que lo han colocado en un plano superior de debate e interés. be extended to most $D C s$ ), the actual numbers have become available only recently. By way of example, the Associaçâo Brasileira de Cimento Portland, ABCP (18) reports that from 1989 to date cement consumption has always been greater in the "informal" than in the "formal" sector and attributes the sustained rise in sales since 1995 to the growth in the number of formiga ${ }^{6}$ consumers, who swallow up over $60 \%$ of cement output (see Figure 5).

Cemex recently (2007) stated in Mexico that it "...ratifies its commitment to self-builders, offering the end consumer high quality products processed with the latest technology with its market launch of a new product, 'Cemento Tolteca', in 25-kilogram bags. This constitutes acknowledgement of the growth of hormiga [micro] cement consumption, which presently accounts for $45 \%$ of the country's cement market" (19). Despite the growth of the Mexican cement market, industry leaders regard it to be an "'immature" market, estimating per capita consumption to be just over 200 kilograms per inhabitant and year and finding that $70 \%$ of the total Mexican cement production is sold in bags, which according to Cemex "...proves that self-building is a force to be reckoned with and differentiates ours from the U.S. market, where $90 \%$ of all cement is sold in bulk".

Moreover, in the self-building market, where purchases tend to be for small amounts and paid in cash, according to the Chairman of Mexico's Federal Competition Commission: "...the price of cement is from $20 \%$ to $25 \%$ higher than the mean price and much higher than the price paid by large-scale consumers, which can be negotiated on the forward market for periods of over 12 months". The retail distribution network for the country's 33 production plants comprises on the order of 30,000 points of sale, which means that plant-to-distribution centre shipping costs account for from $20 \%$ to $30 \%$ of the selling price.

In cement manufacture, the prime materials weigh approximately 30\% more than the actual product. That means that Spain's 38.15 million-tonne output in 2000 consumed on the order of 50 million tonnes of (primarily mineral) raw materials. Since world-wide cement production in 2005 came to 2,220 x109 tonnes, the industry

6 The term consumo hormiga or sector hormiga (micro consumption or micro sector] recently adopted by producers in several Latin American countries is a very literal translation of the deeply rooted Brazilian term sector formiga, which the ABCP has contributed to popularize with specific qualitative papers that have brought it to the fore. 
cemento en 2005 alcanzó los 2.220 MTn, puede extrapolarse a unos $2.900 \mathrm{MTn}$ la cantidad de materias primas empleadas en este sector industrial. Según datos del USGS (26) recogidos en la Tabla 6, puede deducirse que los PVD, son los grandes productores y consumidores de cemento del mundo, con más del $75 \%$ de la producción mundial. Conforme a los datos anteriores, puede deducirse que China, India junto con los países latinoamericanos producen y consumen más de la mitad del cemento mundial.

De la producción mundial de cemento hidráulico en el 2005 (2.220 MTn), fueron China, con 1.000 MTn, India con 130 millones y Estados Unidos con 99.1 MTn los mayores productores de cemento del mundo (20). Cosa bien distinta, son los resultados del consumo de cemento per cápita, ya que según el Informe del Consumo de Cemento ( $n^{\circ}$ 13, abril de 2006) alcanzó en dicho año: $1.200 \mathrm{~kg}$ en España, 803 en Italia, 316 en Alemania... 378 en México y 274 en Chile, por citar unos pocos casos a modo de ejemplos. used about 2,900 $\times 109$ tonnes of prime materials. According to the USGS (26) figures given in Table 6, DCs are the world's major cement producers and consumers, accounting for over $75 \%$ of world-wide output. Further to these data, China, India and the Latin American countries together produce and consume over half of the world's cement.

In 2005, China with one billion (109) tonnes of the world total (2,220 billion), India with 130 million and the United States with 99.1 million were the world's top three hydraulic cement producers (20). The statistics on cement production per capita for that year are a wholly different matter, however, for according to the Informe del Consumo de Cemento (issue 13, April 2006), in Spain the figure was 1,200 kg, in Italy 803, in Germany 316, in Mexico 378 and in Chile 274, to cite a few examples.

Tabla 6 / Table 6

Producción de cemento en millones de toneladas según regiones. Cement production in millions of tonnes by regions.

\begin{tabular}{|l|c|c|c|}
\cline { 2 - 4 } \multicolumn{1}{c|}{} & $\mathbf{2 0 0 0}$ & $\mathbf{2 0 0 1}$ & $\begin{array}{c}\mathbf{2 0 0 2} \text { estimado } \\
\text { (estimate) }\end{array}$ \\
\hline España / Spain & 38,150 & 40,512 & 42,451 \\
\hline $\begin{array}{l}\text { Subtotal Unión Europea } \\
\text { Subtotal European Union }\end{array}$ & 193,106 & 192,396 & 194,461 \\
\hline $\begin{array}{l}\text { Subotal Iberoamérica } \\
\text { Subtotal Latin America }\end{array}$ & 118,807 & 116,347 & 115,212 \\
\hline China / China & 597,000 & 661,040 & 704,720 \\
\hline India / India & 95,000 & 100,000 & 100,000 \\
\hline $\begin{array}{l}\text { Estados Unidos } \\
\text { United States }\end{array}$ & 89,510 & 90,450 & 91,266 \\
\hline $\begin{array}{l}\text { TOTAL (aproximado.) } \\
\text { TOTAL (approximate) }\end{array}$ & $\mathbf{1 ~ 6 5 0 , 0 0 0}$ & $\mathbf{1 ~ 7 3 0 , 0 0 0}$ & $\mathbf{1 ~ 8 0 0 , 0 0 0}$ \\
\hline
\end{tabular}

Fuente: Mineral Yearbook 2002, USGS (20). / Source: Mineral Yearbook 2002, USGS (20).

Ateniéndose a los datos del Banco Mundial (año 2002) (21) sobre el reparto porcentual del total de 6.055 millones habitantes en el 2002: Asia suponía el 60,85\%; África el $12,90 \%$; América Latina el $8,60 \%$ y los Países Desarrollados el $19,6 \%$ y haciendo uso de los valores de producción mundial de cemento facilitados por Oficemen para el mismo año, se ha elaborado la Tabla 7, en la que se constata que el ratio producción de cemento / población, refleja con nitidez los niveles de desarrollo y dinamismo económico de las diferentes áreas geográficas a nivel macroeconómico de las seis regiones contempladas en la tabla.
The World Bank's report (21) on the distribution of the total human population (6.055 x 109) in 2002 shows that $60.85 \%$ lived in Asia, $12.90 \%$ in Africa, $8.60 \%$ in Latin America and $19.6 \%$ in developed countries. Drawing from those data and the world cement output figures published by Oficemen for that year, the cement production / population ratio was calculated and is given in Table 7, which clearly reflects the degree of development and macroeconomic buoyancy of the six regions listed. 
Tabla 7 / Table 7

Producción de cemento según regiones.

Cement production by regions.

\begin{tabular}{|c|c|c|c|c|c|}
\hline $\begin{array}{c}\text { Región } \\
\text { (Año 2002) } \\
\text { Region } \\
\text { (Year 2002) }\end{array}$ & \multicolumn{2}{|c|}{$\begin{array}{l}\text { \% DE LA PRODUCCIÓN } \\
\text { MUNDIAL DE CEMENTO (A) } \\
\text { \% OF WORLD CEMENT } \\
\text { PRODUCTION (A) }\end{array}$} & \multicolumn{2}{|c|}{$\begin{array}{c}\text { \% DE LA POBLACIÓN MUNDIAL } \\
\text { (6.055 M) (B) } \\
\% \text { OF WORLD POPULATION } \\
\text { (6.055 million) (B) }\end{array}$} & $\begin{array}{l}\text { RELACIÓN: (A) / (B) } \\
\text { PRODUCCIÓN / } \\
\text { POBLACIÓN } \\
\text { RATIO: (A) / (B) } \\
\text { PRODUCTION / } \\
\text { POPULATION }\end{array}$ \\
\hline $\begin{array}{l}\text { Europa (Oriental y } \\
\text { Occidental } \\
\text { (Eastern \& Western) } \\
\text { Europe }\end{array}$ & $19,0 \%$ & \multirow{2}{*}{$25,62 \%$} & $\begin{array}{l}\text { Europa Central y } \\
\text { Oriental / Central \& } \\
\text { Eastern Europe } \\
406 \mathrm{M}\end{array}$ & & \\
\hline $\begin{array}{l}\text { América del Norte } \\
\text { North America }\end{array}$ & $6,62 \%$ & & $\begin{array}{c}\text { EEUU / USA } \\
\text { 292,6 M } \\
\text { Canadá / Canada } \\
\text { 31,6 M }\end{array}$ & $19,60 \%$ & 1,307 \\
\hline $\begin{array}{l}\text { Oceania } \\
\text { Oceania }\end{array}$ & \multicolumn{2}{|c|}{$0,0046 \%$} & $\begin{array}{c}\text { Oceanía / Oceania } \\
30.4 \mathrm{M}\end{array}$ & $0,004 \%$ & 1,150 \\
\hline $\begin{array}{l}\text { Asia } \\
\text { Asia }\end{array}$ & \multicolumn{2}{|c|}{$63,0 \%$} & $\begin{array}{c}\text { Asia Meridiona I/ } \\
\text { Southern Asia } \\
1.503 \mathrm{M} \\
\text { Asia Oriental / } \\
\text { Eastern Asia } \\
1.310 \mathrm{M} \\
\end{array}$ & $60,85 \%$ & 1,035 \\
\hline $\begin{array}{l}\text { Latinoamérica } \\
\text { Latin America }\end{array}$ & \multicolumn{2}{|c|}{$6,38 \%$} & $\begin{array}{l}\text { Latinoamérica / } \\
\text { Latin America } \\
540 \text { M }\end{array}$ & $8,60 \%$ & 0,737 \\
\hline $\begin{array}{l}\text { Africa } \\
\text { Africa }\end{array}$ & \multicolumn{2}{|c|}{$5,0 \%$} & $\begin{array}{l}\text { África } \\
\text { Africa } \\
784 \mathrm{M}\end{array}$ & $12,90 \%$ & 0,388 \\
\hline
\end{tabular}

Fuente: los autores sobre las bases mencionadas en el texto. Tabla elaborada para este trabajo.

Source: prepared for this paper from author information as specified in the text.

Con criterios similares a la anterior, se ha elaborado la Tabla 8, en la que se desglosan los valores de la mayoría de países latinoamericanos, incluyendo dos columnas con datos de marcado interés: PIB per cápita en dólares USA (año 2002) y los índices de Desarrollo Humano (IDH) elaborados por el PNUD para el mismo año.

La información directamente deducible de los resultados recogidos en la Tabla 8 puede resultar de interés. Baste señalar, que al tratarse de datos del año 2002, resulta inmediato deducir que los bajos ratios de consumo medio por habitante de Argentina (103 kilos / habitante) y Perú (147 kilos / habitante) muy por debajo de los 219 kilos de la media latinoamericana, son imputables a la difícil situación social y política por la que atravesaron ambos países dicho año. Por otra parte, y en sentido opuesto, los 297 y $271 \mathrm{Kg}$. de México y Venezuela, fueron consecuencia de las alzas de los precios del petróleo en ambos países productores. Bajo resulta el ratio del total de Latinoamérica con $219 \mathrm{~kg}$, lo que también se constata en la Tabla 7 en la que aparece Latinoamérica $(0,737)$ en
Table 8, formulated with similar criteria to provide a breakdown of the values for most Latin American countries, includes two columns with data of particular interest: the GDP per capita in US dollars for 2002 and the human development indices (HDI) published by the UNDP for the same year.

The direct implications of the data in Table 8 are revealing. Since the year chosen was 2002, the low mean consumption ratios per inhabitant in Argentina (103 kg per capita) and Peru (147 kg per capita), which were much lower than the 219-kg Latin American average, are attributable to the social and economic strife prevailing in those countries in the target year. At the same time, at the other end of the spectrum, the 297 and $271 \mathrm{~kg}$ recorded for Mexico and Venezuela, respectively, were the result of the impact of rising oil prices on these two producing countries' economies. The overall ratio for Latin America was low at $219 \mathrm{~kg}$, corroborating the data in Table 7, where the region's cement production/popula- 
una posición casi equidistante de Asia $(1,035)$ y de África $(0,388)$. tion ratio (0.737) was approximately midway between the Asian (1.035) and African (0.388) figures.

Tabla 8 / Table 8

Producción de cemento y otros ratios en países latinoamericanos.

Cement production and other ratios in latin american countries.

\begin{tabular}{|c|c|c|c|c|c|}
\hline $\begin{array}{c}\text { PAÍSES } \\
\text { LATINAOMERICANOS } \\
\text { Y ESPAÑA (REFERENCIA) } \\
\text { COUNTRY }\end{array}$ & $\begin{array}{l}\text { PRODUCCIÓN DE } \\
\text { CEMENTO EN MILES DE } \\
\text { TONELADAS (año 2002) } \\
\text { (A) } \\
\text { CEMENT PRODUCTION } \\
\text { IN MILLIONS OF TONS } \\
\text { (in 2002) } \\
\text { (A) }\end{array}$ & $\begin{array}{c}\text { NÚMERO DE } \\
\text { HABITANTES } \\
\text { EN MILLONES } \\
\text { (año 2002) } \\
\text { (B) } \\
\text { POPULATION, } \\
\text { IN MILLIONS } \\
\text { (in 2002) } \\
\text { (B) }\end{array}$ & $\begin{array}{c}\text { CONSUMO MEDIO } \\
\text { POR HABITANTE Y } \\
\text { AÑO } \\
\text { C }=(A) /(B) \\
\text { AVERAGE } \\
\text { CONSUMPTION } \\
\text { PER INHABITANT } \\
\text { AND YEAR } \\
C=(A) /(B)\end{array}$ & $\begin{array}{l}\text { P.I.B. EN } \\
\text { DÓLARES } \\
\text { USA PER } \\
\text { CÁPITA } \\
\text { (año 2002) } \\
\text { PER CAPITA } \\
\text { GDP IN USD } \\
\text { (in 2002) }\end{array}$ & $\begin{array}{c}\text { ÍNDICE DE } \\
\text { DESARROLLO } \\
\text { HUMANO (2002) } \\
\left(^{*}\right) \\
\text { HUMAN } \\
\text { DEVELOPMENT } \\
\text { INDEX (2002) } \\
\left(^{*}\right)\end{array}$ \\
\hline $\begin{array}{l}\text { Brasil } \\
\text { Brazil }\end{array}$ & 39,500 & 181,4 & 218 & 7.790 & 73 \\
\hline $\begin{array}{l}\text { México } \\
\text { Mexico } \\
\end{array}$ & 31,069 & 104,7 & 297 & 9.168 & 54 \\
\hline $\begin{array}{l}\text { Colombia } \\
\text { Colombia }\end{array}$ & 9,800 & 44,2 & 222 & 6.702 & 68 \\
\hline $\begin{array}{l}\text { Venezuela } \\
\text { Venezuela }\end{array}$ & 7,000 & 25,8 & 271 & 4.919 & 69 \\
\hline $\begin{array}{l}\text { Argentina } \\
\text { Argentina }\end{array}$ & 3,910 & 38,0 & 103 & 12.106 & 34 \\
\hline $\begin{array}{l}\text { Perú } \\
\text { Peru }\end{array}$ & 4,000 & 27,2 & 147 & 5.260 & 82 \\
\hline $\begin{array}{l}\text { Chile } \\
\text { Chile }\end{array}$ & 3,600 & 16,0 & 225 & 10.274 & 38 \\
\hline $\begin{array}{l}\text { Ecuador } \\
\text { Ecuador }\end{array}$ & 2,860 & 12,9 & 222 & 3.641 & 93 \\
\hline $\begin{array}{l}\text { El Salvador } \\
\text { El Salvador }\end{array}$ & 1,318 & 6,6 & 200 & 4.781 & 104 \\
\hline $\begin{array}{l}\text { R. Dominicana } \\
\text { Dominican } R \text {. }\end{array}$ & 3,071 & 8,6 & 357 & 6.823 & 94 \\
\hline $\begin{array}{l}\text { Otros }(* *) \\
\text { Others }\end{array}$ & 9,084 & 60,8 & 149 & & \\
\hline $\begin{array}{l}\text { Total Latinoamérica } \\
\text { Total Latin America }\end{array}$ & 115,212 & & 219 & & \\
\hline $\begin{array}{l}\text { España } \\
\text { Spain }\end{array}$ & 42,451 & 42,1 & 1.008 & 22.381 & 21 \\
\hline
\end{tabular}

Fuente: los autores sobre las bases mencionadas en el texto. Tabla elaborada para este trabajo con las acotaciones que siguen:

${ }^{*}$ ) El índice de Desarrollo Humano, IDH, aceptado universalmente, lo elabora anualmente el Programa de Naciones Unidas para el Desarrollo (PNUD), sobre la base de los progresos de los países (173 evaluados) en términos de 'esperanza de vida', 'logros educacionales' e 'ingreso real ajustado'.

(*) Incluye a Cuba, Guatemala, Costa Rica, Honduras, Bolivia, Panamá, Paraguay, Uruguay y Nicaragua.

Source: prepared for this paper from author information as specified in the text.

(*) The widely accepted Human Development Index, HDI, is computed annually by the United Nations Development Programme (UNDP)on the basis of countries' progress (173 assessed) in terms of life expectancy, educational achievement and adjusted income.

$(* *)$ Cuba, Guatemala, Costa Rica, Honduras, Bolivia, Panama, Paraguay, Uruguay and Nicaragua.

De los 209 países que conforman el mundo, 113 producen cemento con una capacidad instalada del orden de 2.740 millones de toneladas, de lo que puede deducirse que casi un centenar de países no cuentan con plantas productoras de cemento y que la gran mayoría de ellos o son estados pequeños o se encuentran entre los que detentan los Índices de Desarrollo Humano (IDH) más altos en la lista del PNUD.
Slightly over half, or 113 of the world's 209 countries, produce cement with a combined installed capacity on the order of $2.740 \times 109$ tonnes. Most of the nearly one hundred countries that have no cement plants are either small states or nations with the highest UNDP human development index (HDI) values. 


\section{A MODO DE CONCLUSIONES}

En el caso concreto de Latinoamérica, resulta importante señalar que en varios subsectores de la producción de materiales de construcción (ver Tabla 9) la participación desmedida de las importaciones repercute negativamente en la propia estructura de costes. Hasta bien reciente (este hecho ha cambiado sensiblemente con el nuevo siglo) se procedía con demasiada ligereza a la importación de materiales y componentes básicos, que fácilmente hubieran podido ser reemplazados por productos nacionales y por materiales alternativos. Este hecho refleja la debilidad del parque industrial regional para cubrir adecuadamente los grandes incrementos de la demanda, como ya advertía la Comisión para América Latina (CEPAL) en 1994 (22). En base únicamente a la experiencia de los autores, por carecer de datos universalmente aceptados y contrastables, puede afirmarse, sin embargo, que en este aspecto específico la situación en África es muy distinta y las carencias del sector productivo de materiales básicos de construcción son ciertamente críticas y, por tanto, difícilmente comparables con las del caso latinoamericano (23).

El equipo de técnicos del trabajo de CEPAL mencionado, se mostraba partidario de que los gobiernos fomentasen y apoyasen el suministro de materiales básicos de la construcción de producción local, asequibles y duraderos; opinión que también comparten los autores y que pasan a explicitar en las siguientes propuestas concretas, las cuales han de entenderse en el contexto de un marco global:

a) Alentar y apoyar el establecimiento y la expansión de pequeñas industrias locales dedicadas a la producción de materiales de construcción, así como la expansión de su comercialización recurriendo a incentivos legales y fiscales, concesión de créditos, proyectos de investigación aplicada y campañas de información.

b) Adoptar políticas que favorezcan la competencia en el mercado de materiales de construcción con mayor participación de entidades locales.

c) Fomentar el intercambio de información sobre tecnologías apropiadas y apropiables de construcción: sustentables, racionales, asequibles, accesibles y fáciles de transferir.

d) Prestar la debida atención a las necesidades en materia de seguridad ante posibles catástrofes debidas a fenómenos naturales, sin que ello suponga la prohibición indiscriminada de utilización de materiales autóctonos de construcción de bajo costo en viviendas.

e) Crear mecanismos para la producción y distribución comercial de materiales de construcción básicos destinados a programas de autoconstrucción asistida.

\section{BY WAY OF CONCLUSION}

In the specific case of Latin America, the inordinate share of imports in a number of construction materials subindustries (see Table 9) has an adverse effect on cost structures. Until very recently (this situation began to change appreciably at the turn of the century), basic materials and components that could have readily been replaced by domestic products or alternative materials were imported too rashly. This is an indication of the regional industry's inability to suitably meet large increases in demand, a shortcoming identified by the Economic Commission for Latin America and the Caribbean (ECLAC) as early as 1994 (22). Based solely on the authors' experience, given the want of universally accepted and verifiable data, in this specific regard the situation may be said to be very different in Africa, where the shortage of basic construction materials is critical and hardly comparable to circumstances in Latin America (23).

The team that drafted the ECLAC paper cited above supported governmental furtherance of and support for the supply of locally produced, affordable and durable basic building materials. This opinion is shared by the present authors, who put forward the following specific proposals, which should be interpreted in a global context:

a) Encouragement of and support for the establishment and expansion of small local industries engaging in construction material manufacture and the expansion of their distribution networks through legal and tax incentives, loan facilities, applied research and information campaigns.

b) Adoption of policies that favour competition in the construction materials market, with greater participation on the part of local organizations.

c) Furtherance of the exchange of information on technologies suitable for and that can be assimilated by construction: sustainable, rational, affordable and readily transferable.

d) Due attention to safety needs in the context of natural disasters without adopting this as an excuse for the indiscriminate prohibition of the use of autochthonous, low-cost building materials in housing.

e) Creation of mechanisms for the production and commercial distribution of basic construction materials geared to assisted self-construction programmes. 
Para estimular y mejorar el desarrollo del sector 'informal' de materiales de construcción, ONUDI (8) proponía hace cinco lustros, entre otras, las recomendaciones que siguen y que en su momento comentó uno de los autores en esta misma revista de Materiales de Construcción (24):

I.- Reconocer la importancia de la producción de elementos y materiales de construcción del sector "informal" y prestar pleno apoyo a los proyectos encaminados al desarrollo de este sector.

II.- Facilitar, en proyectos de construcción estatales, el empleo de materiales de construcción producidos por el sector no estructurado;

III.- Alentar la aceptación, y en su caso, la elaboración de normas y especificaciones que permitan el empleo de materiales y elementos producidos por el sector "informal" y englobar sistemáticamente estos materiales y elementos en las reglamentaciones de construcción mediante el concepto de niveles de exigencia;

IV.- Reforzar los vínculos entre las actividades de investigación competitiva de ámbito nacional o internacional con necesidades específicas del sector no estructurado.

V.- Ayudar a difundir y formular normas y especificaciones para materiales locales.

Pese a los muchos años transcurridos, los autores estiman vigentes en plenitud las recomendaciones de ONUDI, y consideran plausible concitar el debate y la reflexión entre investigadores y técnicos del sector sobre los grandes retos que ha de afrontar la industria de materiales básicos de edificación ante las ingentes necesidades actuales.
Twenty five years, ago UNIDO (8) proposed the recommendations listed below to foster and improve the development of the "informal" construction materials industry, which one of the authors of this paper discussed in this journal (24) at the time:

I.- Acknowledgement of the importance of the production of construction elements and materials by the "informal" sector and provision of full support for projects geared to developing this sector;

II.- Enabling of the use of construction materials produced by the non-structured industry in State construction projects;

III.-Encouragement of the acceptance of materials and elements produced by the "informal" sector and as appropriate, formulation of standards and specifications allowing their use, systematically including these materials and elements in construction regulations in the form of different requirement levels;

IV.- Reinforcement of the links between national or international competitive research and the specific needs of the non-structured sector;

V.- Assistance in the publication and formulation of standards and specifications for local materials.

Despite the time that has lapsed, the authors find these UNIDO recommendations to be fully relevant today, and deem that industry researchers, architects and engineers can be encouraged to debate and reflect on the major challenges facing the basic building materials industry as a result of today's daunting needs.

\section{BIBLIOGRAFÍA / BIBLIOGRAPHY}

(1) WACLA: 1996, World Assembly of Cities and Local Authorities: Soluciones locales y problemas globales: El futuro de los asentamientos humanos. Estambul 31.05. (1996).

(2) Tibaijuka, A.: 2007, "Ante el Día Mundial del Hábitat", UN - HABITAT, Nairobi, 12.05.2007

(3) Naciones Unidas: 2003, World Population Prospects: The 2002 Revision. Nairobi, 2002.

(4) COHRE: 2003, Centre on Housing Rights and Evictions, Global Survey no 8, Ginebra Suiza.

(5) UN HABITAT: 1996, United Nations Centre for Human Settlements (Hábitat): Informe Mundial sobre los Asentamientos Humanos, ISBN 92-1-331015-3.

(6) Mac Donald, J.: "Pobres en ciudades pobres", ponencia en el I Congreso Internacional sobre Desarrollo Humano, Ayuntamiento de Madrid, nov. (2006).

(7) UN HABITAT 2003, "Improving the lives of 100 million slum dwellers", Global Observatory, Un-HABITAT, Nairobi (Kenya).

(8) Banco Mundial: 2005, World Development Indicators: www.worldbank.org/poverty/wdrpoverty

(9) Millenium Project: 2006, Mejorar las condiciones de vida de los chabolistas, Un hogar en la ciudad, Ministerio de Vivienda (España), Madrid, (2007).

(10) ONUDI: First Consultation on Building Material, Atenas, marzo (1985).

(11) Ortega y Gasset, J.: "Meditación de la técnica", Charla en Buenos Aires, 1952. Edit. Alianza, Revista de Occidente, Madrid (2000).

(12) Salas, J.: La industrialización "posible" de la vivienda latinoamericana. Edit. ESCALA, Bogotá, Colombia (2000).

(13) Gonçalves, R.: "Documento sobre situaçao atual da habitaçao na Regiao Metropolitana de Belo Horizonte" (1997), mimeo.

(14) Torrealba, E.: "Construcción de viviendas de bajo coste en Chile: el caso de Rancagua", CEPAL (1999). 
(15) O.P.E. El Salvador, Oficina de Planificación Estratégica de El Salvador: "Propuestas para la transformación de los procesos de gestión de proyectos y análisis de casos en viviendas" (1997).

(16) Houben, H. L.: "habitat èconomique dans les pays en developpemenr: materiaux, techniques de constructio. Plan Construcción. Paris (1993), Vol. 2 págs. 53 a 56.

(17) Cortinez, J. M.: Los materiales de construcción: Base industrial de la producción de vivienda, Cap. 4 "La producción de la Vivienda en América Latina", CEPAL, Santiago de Chile (1996).

(18) Campos, P. E.: "Industrialização da construção e argamassa armada; perspectivas de desenvolvimento". São Paulo, EPUSP, 1989.

(19) Gastelum, G.: Director de Comunicaciones Externas de Apasco, Cemex (2007). Comunicado del 7.09.2007.

(20) USGS: Mineral Yearbook (2002).

(21) Banco Mundial: World Development Report, 2000/2001 Attacking poverty (2001) www.worldbank.org

(22) CEPAL: Alojar el Desarrollo: Una tarea para los asentamientos humanos. Documento LC/L906. CONF. 85/3. Ver: Julián Salas, Actas de la Reunión CYTED: Iberoamérica ante Hábitat II. Ministerio de Fomento, Madrid (1996).

(23) Ganesan, S.: "Employement maximization in construction in developing countries". Construction Management and Economics, №. 12, pp. 323-335 (1994). http://dx.doi.org/10.1080/01446199400000042

(24) Salas, J.: "Respuestas a la Primera Consulta sobre la industria de los Materiales de Construcción de ONUDI", Mater. Construcc., Vol. 35, Madrid (junio 1985).

(25) Rodríguez, E., Bernal, S., Mejía de Gutiérrez, R., Puertas, F.: "Hormigón alternativo basado en escorias activadas alcalinamente". Mater. Construcc., vol. 58, no 291, pp. 53-67 (2008). 